\title{
A Facile and Efficient One-Pot Regioselective Synthesis of 2-Hydroxyalkyl Dithiocarbamates under Catalyst-Free Conditions
}

\author{
Barahman Movassagh*, Bahareh Shokri \\ Department of Chemistry, K. N. Toosi University of Technology, Tehran, Iran \\ Email: "bmovass1178@yahoo.com
}

Received May 28, 2012; revised June 29, 2012; accepted July 8, 2012

\begin{abstract}
A simple catalyst-free, and highly regioselective approach to 2-hydroxyalkyl dithiocarbamates is described which involves a one-pot reaction of various amines and carbon disulfide, $\mathrm{CS}_{2}$, with epoxides in ethanol at room temperature.
\end{abstract}

Keywords: 2-Hydroxyalkyl Dithiocarbamates; Epoxides; Regioselective; Amines; Carbon Disulfide

\section{Introduction}

The formation of carbon-sulfur bond, especially under a green and safe condition, is an important transformation in organic synthesis. Sulfur containing compounds are found in many products of biological [1-4] and medical [5-7] relevance as well as in commercial drugs [8].

Dithiocarbamates are a class of fungicides extensively used worldwide on a range of crops mainly due to their efficiency in controlling plant fungal diseases and relatively low mammalian acute toxicity [9]. They have also received much attention due to their wide utility as potent anticancer agents [10,11] and cell apoptosis inhibitors [12-14]. Dithiocarbamates have found applications in the rubber industry as vulcanization accelerators [15], in controlled radical polymerization techniques [16-18], and recently in the synthesis of ionic liquids [19]. They also act as linkers in the solid-phase organic synthesis [20-22], and for protection of amine groups in peptide synthesis [23]. They are usually synthesized by several available methodologies [24-33].

In recent years, much attention has been paid to functionalized dithiocarbamates; among them, 2-hydroxy dithiocarbamates represent an important class of key compounds that have been used for various applications, especially as synthetic intermediates [34-36], as multifunctional lubricant additives [37,38], and as electrophotographic liquid developers $[39,40]$. They are usually synthesized by one of the following main methods: (1) reaction of an amine and carbon disulfide, to form dithiocarbamic acid salt, with epoxides [41,42], or with 2-hydroxyalkyl halides [43], and (2) reaction of amino-thio-

${ }^{*}$ Corresponding author. carboxylic halides with 1,2-mercapto ethanol derivatives [44]. However, some of these procedures suffer from long reaction times, use of low temperatures, use of large excess of toxic carbon disulfide, use of strong basic conditions, and low to moderate yields of products. In two recent reports 2-hydroxy dithiocarbamates were directly prepared from primary or secondary amines, carbon disulfide and epoxides in acetone and in the presence of anhydrous potassium phosphate [41], and in catalyst- and solvent-free conditions [42]; in both methods, addition of an amine to $\mathrm{CS}_{2}$ was slow, maintaining the temperature at around $0^{\circ} \mathrm{C}$ followed by addition of an epoxide at room temperature.

\section{Results and Discussion}

One important issue in green chemistry which is currently receiving an increasing attention is the use of alternative reaction media that circumvent the problems associated with many of the traditional toxic and volatile organic solvents. Many issues surrounding a wide range of volatile and non-volatile, polar aprotic solvents have stimulated fine chemical and pharmaceutical industries to seek more benign alternatives [45]; there is a marked trend away from hydrocarbons and chlorinated hydrocarbons towards lower alcohols and ethers [45].

As part of our research to develop practical, simple, and green methodologies in organic synthesis [46-58], herein we describe an efficient, catalyst-free synthesis of 2-hydroxyalkyl dithiocarbamates from primary or secondary amines and $\mathrm{CS}_{2}$ with epoxides in ethanol (Scheme 1).

In order to optimize the reaction condition with respect to solvent, time, temperature, and molar ratios of the 
components, the reaction of 2,3-epoxypropyl phenyl ether with benzylamine and carbon disulfide was planned as a model reaction in the absence of any catalyst. It was found that by simple initial mixing of benzylamine $(1.2$ mmol) and carbon disulfide $(1.3 \mathrm{mmol})$ in ethanol $(1.5$ $\mathrm{mL})$ at room temperature, followed by addition of the epoxide $(1.0 \mathrm{mmol})$ at that temperature, the expected dithiocarbamates were obtained in 92\% yield within a very short time. The reaction was also conducted in water but under the same reaction condition as above; however, it yielded no expected product even after $3.5 \mathrm{hrs}$.

To explore the generality and scope of this method, various amines (primary, secondary, benzylic and aromatic) and epoxides were examined under the conditions outlined above. As it can be seen from Table 1, the reaction of primary, secondary, and benzylic amines with epoxides are generally very fast (5 - 15 mins), clean and high yielding (60\% - 98\%), except for aniline (Table 1, Entry 9) which gave the corresponding dithiocarbamates but in poor yield (12\%) even after 120 mins. In fact, as expected in a typical nucleophilic addition, aliphatic amines show higher reactivity than the aromatic ones. In all cases reported, only one single product was isolated. ${ }^{1} \mathrm{H}$ NMR Analysis of the pure dithiocarbamates obtained from their reaction with unsymmetrical epoxides revealed that in most cases the nucleophile predominantly attacks the less hindered carbon of the epoxide (C-a) (Table 1, Entries 1 - 6 and $10-14$ ) to give mainly the regioisomer 3 (Scheme 1). However, under the same conditions, no selectivity was observed for styrene oxide, and both regioisomers 3 and 4 were formed (Table 1, Entries 15 - 18). As expected, in aliphatic epoxides steric factors predominate over electronic effects.

We assume that the unstable dithiocarbamic acid 5, initially generated from the amine and $\mathrm{CS}_{2}$, reacts with the epoxide 2 giving rise to the formation of the 2-hydroxyalkyl dithiocarbamates 3 and 4 (Scheme 2).

\section{Conclusion}

To conclude, we have developed a very convenient and efficient regioselective and catalyst-free protocol for the one-pot reaction of various aliphatic/aromatic amines and $\mathrm{CS}_{2}$ with different epoxides in ethanol at room temperature. In this fast and high yielding method, the use of low temperature is avoided.

\section{Experimental}

\subsection{General}

Melting points were recorded on a Buchi B-540 apparatus and were uncorrected. IR spectra were recorded on an ABB FTLA 2000 instrument. NMR spectra were recorded with either a Bruker AQS-300 or Bruker DRX-500 spec- trometer with nominal frequencies of $300 \mathrm{MHz}$ and 500 $\mathrm{MHz}$ for proton or 75 and $125 \mathrm{MHz}$ for carbon, respecttively in $\mathrm{CDCl}_{3}$ using TMS as an internal standard.

\subsection{General Experimental Procedure for Preparation of 2-Hydroxyalkyl Dithiocarbamates}

A stirred solution of carbon disulfide $(1.3 \mathrm{mmol})$ in EtOH $(1.5 \mathrm{ml})$ was slowly treated with the amine (1.2 mmol); the mixture was stirred for 15 mins at room temperature, followed by addition of the epoxides $(1.0 \mathrm{mmol})$ in one portion; stirring, at room temperature, was continued for the length of time indicated in Table 1. After completion of the reaction, ethanol was evaporated, $\mathrm{Et}_{2} \mathrm{O}$ $(10 \mathrm{ml})$ was added, and the mixture was washed with water $(2 \times 5 \mathrm{ml})$, and the organic layer was dried $\left(\mathrm{Na}_{2} \mathrm{SO}_{4}\right)$. The solvent was evaporated under reduced pressure, and the crude mixture was purified by preparative TLC (silica gel: eluent, $n$-hexane/EtOAc $=2: 1$ ).

\section{Selected Physical and Spectral Data}

2-Hydroxypropyl $n$-Butyl Carbamodithioate (3b) [42] Colorless oil; IR (neat): $v_{\max }=750,922,1039,1125$, 1406, 3224, $3373 \mathrm{~cm}^{-1}$; ${ }^{1} \mathrm{H}$ NMR (300 MHz, $\left.\mathrm{CDCl}_{3}\right): \delta=$ 0.88 (t, $J=7.2 \mathrm{~Hz}, 3 \mathrm{H}), 1.23$ (d, $J=6.2 \mathrm{~Hz}, 3 \mathrm{H}), 1.34$ (sext, $J=7.1 \mathrm{~Hz}, 2 \mathrm{H}$ ), 1.58 (quin, $J=7.6 \mathrm{~Hz}, 2 \mathrm{H}$ ), 3.13 (dd, $J=14.7,7.1 \mathrm{~Hz}, 1 \mathrm{H}$ ), 3.34 (dd, $J=14.7,3.2 \mathrm{~Hz}$, 1H), 3.5 (br s, 1H), 3.63 (q, $J=6.9 \mathrm{~Hz}, 2 \mathrm{H}), 4.06-4.09$ (br m, 1H), 8.44 (br s, $1 \mathrm{H}) .{ }^{13} \mathrm{C}$ NMR (75 MHz, $\mathrm{CDCl}_{3}$ ): $\delta=13.6,20.1,22.4,30.2,43.4,47.3,67.7,197.2$.

2-Hydroxybutyl Pyrrolidine-1-Carbodithioate (3d) [42] Colorless oil; IR (neat): $v_{\max }=750,1219,1432,1463$, $3404 \mathrm{~cm}^{-1}$; ${ }^{1} \mathrm{H}$ NMR (300 MHz, $\mathrm{CDCl}_{3}$ ): $\delta=1.00$ (t, $J=$ $7.4 \mathrm{~Hz}, 3 \mathrm{H}$ ), 1.60 (quin, $J=7.3 \mathrm{~Hz}, 2 \mathrm{H}$ ), 1.97 (quin, $J=$ $6.9 \mathrm{~Hz}, 2 \mathrm{H}$ ), 2.09 (quin, $J=6.9 \mathrm{~Hz}, 2 \mathrm{H}$ ), 2.56 (br s, $1 \mathrm{H}$ ), 3.38 (dd, $J=14.3,7.4 \mathrm{~Hz}, 1 \mathrm{H}), 3.66-3.75$ (m, 3H), 3.82 - $3.86(\mathrm{~m}, 1 \mathrm{H}), 3.93$ (t, $J=6.9 \mathrm{~Hz}, 2 \mathrm{H})$.

2-Hydroxybutyl Benzylcarbamodithioate (3f) [42] Yellow oil; IR (neat): $v_{\max }=703,750,938,1094,1234$, 1391, 1499, 3209, $3337 \mathrm{~cm}^{-1}$; ${ }^{1} \mathrm{H}$ NMR (300 MHz, $\mathrm{CDCl}_{3}$ ): $\delta=0.91$ (t, $J=7.3 \mathrm{~Hz}, 3 \mathrm{H}$ ), 1.51 (quin, $J=7.4$ $\mathrm{Hz}, 2 \mathrm{H}), 3.13$ (dd, $J=14.7,7.6 \mathrm{~Hz}, 1 \mathrm{H}), 3.36$ (dd, $J=$ 14.7, $3.1 \mathrm{~Hz}, 1 \mathrm{H}$ ), 3.40 (br s, $1 \mathrm{H}), 3.72-3.77$ (m, $1 \mathrm{H})$, 4.84 (d, $J=5.3 \mathrm{~Hz}, 2 \mathrm{H}), 7.25-7.34$ (m, 5H), 8.75 (br t, $1 \mathrm{H}) ;{ }^{13} \mathrm{C}$ NMR $\left(75 \mathrm{MHz}, \mathrm{CDCl}_{3}\right): \delta=10.0,29.3,41.8$, 51.1, 72.9, 127.9, 128.2, 128.8, 136.2, 198.1.

2-Hydroxy-3-Phenoxypropyl Piperidine-1-Carbamodithioate (3n) [42] Yellow oil; IR (KBr): $v_{\max }=1601$, 2926, $3404 \mathrm{~cm}^{-1}$; ${ }^{1} \mathrm{H}$ NMR (300 MHz, $\mathrm{CDCl}_{3}$ ): $\delta=1.64$ (br s, 6H), 3.62 (dd, $J=14.3,6.9 \mathrm{~Hz}, 2 \mathrm{H}$ ), 3.80 (dd, $J=$ 14.5, $3.8 \mathrm{~Hz}, 1 \mathrm{H}$ ), 3.86 (br s, 2H), 4.05 (t, $J=4.8 \mathrm{~Hz}, 2 \mathrm{H}$ ), 4.2-4.31 (m, 3H), 6.90 - 6.96 (m, 3H), 7.23-7.28 (m, 2H); ${ }^{13} \mathrm{C}$ NMR (75 MHz, $\left.\mathrm{CDCl}_{3}\right): \delta=24.2,25.5,26.0,39.9$, 51.6, 53.5, 69.6,70.5, 114.6, 121.1, 129.5, 158.5, 195.4. 
Table 1. Regioselective ring opening of epoxides in EtOH under catalyst-free conditions.

\begin{tabular}{|c|c|c|c|c|c|c|}
\hline Entry & Epoxide & Amine & $\begin{array}{l}\text { Reaction } \\
\text { Time (min) }\end{array}$ & Product & Yield $^{\mathrm{a}, \mathrm{b}}(\%)$ & $\begin{array}{c}\text { Regioselectivity } \\
3: 4\end{array}$ \\
\hline 1 & & & 8 & За & 94 & $100: 0$ \\
\hline 2 & & & 12 & $3 b$ & 91 & $82: 18$ \\
\hline 3 & & & 8 & 3c & 95 & 100: 0 \\
\hline 4 & & & 6 & 3d & 94 & $100: 0$ \\
\hline 5 & & & 7 & 3e & 94 & 100:0 \\
\hline 6 & & & 12 & $3 f$ & 89 & $88: 12$ \\
\hline 7 & & & 12 & $3 g$ & 60 & - \\
\hline 8 & & & 13 & $3 \mathrm{~h}$ & 64 & - \\
\hline 9 & & $\mathrm{PhNH}_{2}$ & 120 & $3 \mathrm{i}$ & 12 & - \\
\hline 10 & & & 8 & $3 \mathrm{j}$ & 92 & 100:0 \\
\hline 11 & & & 7 & $3 \mathrm{k}$ & 93 & $81: 19$ \\
\hline 12 & & & 5 & 31 & 98 & 100:0 \\
\hline 13 & & & 10 & $3 m$ & 90 & $82: 18$ \\
\hline 14 & & & 4 & $3 n$ & 96 & $100: 0$ \\
\hline 15 & & & 10 & $30 / 40$ & 90 & $35: 65$ \\
\hline 16 & & & 10 & $3 p / 4 p$ & 91 & $57: 43$ \\
\hline 17 & & & 15 & $3 q / 4 q$ & 83 & $33: 67$ \\
\hline 18 & & & 12 & $3 r / 4 r$ & 88 & $62: 38$ \\
\hline
\end{tabular}

${ }^{\mathrm{a}}$ Isolated yield of $3+4$; ${ }^{\mathrm{b}}$ Reference for known compounds [42]. 
<smiles>[R12]N=[13CH][C@H]1O[C@@H]1[R]</smiles>

Scheme 1. Preparation of 2-hydroxyalkyl dithiocarbamates.<smiles>[R2]N[Sb]</smiles><smiles>[R12]NC(=S)SC([R3])CO</smiles>

Scheme 2. Proposed mechanism of formation of the dithiocarbamates.

\section{Acknowledgements}

We wish to thank Dr. Sogand Noroozizadeh for editing the manuscript and the K. N. Toosi University of Technology Research Council for financial support of this work.

\section{REFERENCES}

[1] Z. Cai, W. Zhou and L. Sun, "Synthesis and HMG CoA Reductase Inhibition of 4-Thiophenyl Quinolines as Potential Hypocholesterolemic Agents," Bioorganic \& Medicinal Chemistry, Vol. 15, No. 24, 2007, pp. 7809-7829. doi:10.1016/j.bmc.2007.08.044

[2] J. Kendall, G. Rewcastle, R. Frederick, C. Mawson, W. Denny, E. Marshall, B. Baguley, C. Chaussade, S. Jackson and P. Shepherd, "Synthesis, Biological Evaluation and Molecular Modelling of Sulfonohydrazides as Selective PI3K p110 $\alpha$ Inhibitors,” Bioorganic \& Medicinal Chemistry, Vol. 15, No. 24, 2007, pp. 7677-7687.

[3] Y. Kanda, T. Ashizawa, K. Kawashima, S. Ikeda and T. Tamaoki, "Synthesis and Antitumor Activity of Novel C-8 Ester Derivatives of Leinamycin," Bioorganic \& Medicinal Chemistry Letters, Vol. 13, No. 13, 2003, pp. 455458.

[4] A. Tyrkov, N. Urlyapova and A. Daudova, "Synthesis and Antimycobacterial Activity of Substituted 2-Nitro-1-(4-tolfonyl)-2-(3-methylphenyl-1,2,4-oxadiazol-5-yl)Ethanes,” Pharmaceutical Chemistry Journal, Vol. 40, No. 7, 2006, pp. 377-379. doi:10.1007/s11094-006-0131-6

[5] C. Jacob, "A Scent of Therapy: Pharmacological Implications of Natural Products Containing Redox-Active Sulfur Atoms," Natural Product Reports, Vol. 23, No. 6, 2006, pp. 851-863.
[6] X. Y. Wang and Z. J. Guo, "The Role of Sulfur in Platinum Anticancer Chemotherapy," Anti-Cancer Agents in Medicinal Chemistry, Vol. 7, No. 1, 2007, pp. 19-34. doi:10.2174/187152007779314062

[7] T. Ariga and T. Seki, "Antithrombotic and Anticancer Effects of Garlic-Derived Sulfur Compounds: A Review," BioFactors, Vol. 26, No. 2, 2006, pp. 93-103. doi:10.1002/biof.5520260201

[8] A. van Zanten, M. Oudijk, M. Nohlmans-Paulssen, Y. van der Meer, A. Girbes and K. Polderman, "Continuous vs. Intermittent Cefotaxime Administration in Patients with Chronic Obstructive Pulmonary Disease and Respiratory Tract Infections: Pharmacokinetics/ Pharmacodynamics, Bacterial Susceptibility and Clinical Efficacy," British Journal of Clinical Pharmacology, Vol. 63, No. 1, 2007, pp. 100-109. doi:10.1111/j.1365-2125.2006.02730.x

[9] E. D. Caldas, M. H. Conceicão, M. C. C. Miranda, L. C. K. R. de Souza and J. F. Lima, "Determination of Dithiocarbamate Fungicide Residues in Food by a Spectrophotometric Method Using a Vertical Disulfide Reaction System," Journal of Agricultural and Food Chemistry, Vol. 49, No. 10, 2001, pp. 4521-4525. doi:10.1021/jf010124a

[10] Y. Zhang and P. Talalay, "Anticarcinogenic Activities of Organic Isothiocyanates-Chemistry and Mechanisms," Cancer Research, Vol. 54, Suppl. 7, 1994, pp. S1976S1981.

[11] L. Ronconi, C. Marzano, P. Zanello, M. Corsini, G. Miolo, C. Macca, A. Trevisan and D. Fregona, “Gold(III) Dithiocarbamate Derivatives for the Treatment of Cancer: Solution Chemistry, DNA Binding, and Hemolytic," Journal of Medicinal Chemistry, Vol. 49, No. 5, 2006, pp. 1648-1657. doi:10.1021/jm0509288

[12] R. Bessho, K. Matsubara and M. Kubota, "Pyrrolidine 
Dithiocarbamate, a Potent Inhibitor of Nuclear Factor Kappa-B (NF-Kappa-B) Activation, Prevents Apoptosis in Human Promyelocytic Leukemia HL-60 Cells and Thymocytes," Biochemical Pharmacology, Vol. 48, No. 10, 1994, pp. 1883-1889. doi:10.1016/0006-2952(94)90586-X.

[13] C. S. I. Nobel, M. Kimland and B. Lind, "Dithiocarbamates Induce Apoptosis in Thymocytes by Raising the Intracellular Level of Redox-Active Copper," Journal of Biological Chemistry, Vol. 270, No. 44, 1995, pp. 2620226208.

[14] J. C. Tsai, M. Jain and C. M. Hsieh, "Induction of Apoptosis by Pyrrolidinedithiocarbamate and N-Acetylcysteine in Vascular Smooth Musclecells," Journal of Biological Chemistry, Vol. 271, No. 7, 1996, pp. 3667-3670. doi:10.1074/jbc.271.7.3667

[15] P. J. Nieu Wenhuizen, A. W. Ehlers, J. G. Haasnoot, S. R. Janse, J. Reedijk and E. J. Baerends, "The Mechanism of Zinc(II)-Dithiocarbamate-Accelerated Vulcanization Uncovered; Theoretical and Experimental Evidence," Journal of the American Chemical Society, Vol. 121, No. 1, 1999, pp. 163-168. doi:10.1021/ja982217n

[16] M. R. Wood, D. J. Duncalf, S. P. Rannard and S. Perrier, "Selective One-Pot Synthesis of Trithiocarbonates, Xanthates, and Dithiocarbamates for use in RAFT/MADIX Living Radical Polymerizations,” Organic Letters, Vol. 8, No. 4, 2006, pp. 553-556. doi:10.1021/ol0525617

[17] S. Z. Zard, "On the Trail of Xanthates: Some New Chemistry from an Old Functional Group," Angewandte Chemie International Edition in English, Vol. 36, No. 7, 1997, pp. 673-685. doi:10.1002/anie.199706721

[18] D. H. R. Barton, "The Invention of Chemical ReactionsThe Last Five Years,” Tetrahedron, Vol. 48, No. 13, 1992, pp. 2529-2544.

[19] D. Zhang, J. Chen, Y. C. Liang and H. Zhou, "Facile Synthesis of Novel Ionic Liquids Containing Dithiocarbamate," Synthetic Communications, Vol. 35, No. 4, 2005, pp. 521-526.

[20] A. D. Dunn and W.-D. Rudorf, "Carbon Disulfide in Organic Chemistry,” Ellis Horwood, Chichertes, 1989.

[21] A. McClain and Y.-L. Hsieh, "Synthesis of Polystyrene-Supported Dithiocarbamates and Their Complexation with Metal Ions," Journal of Applied Polymer Science, Vol. 92, No. 1, 2004, pp. 218-225. doi:10.1002/app.13623

[22] P. Morf, F. Raimondi, H.-G. Nothofer, B. Schnyder, A. Yasuda, J. M. Wessels and T. A. Jung, "Dithiocarbamates: Functional and Versatile Linkers for the Formation of Self-Assembled Monolayers,” Langmuir, Vol. 22, No. 2, 2006, pp. 658-663. doi:10.1021/la052952u

[23] T. W. Greene and P. G. M. Wuts, "Protecting Groups in Organic Synthesis,” 3rd Edition, Wiley Interscience, New York, 1999.

[24] T. R. Burke Jr., B. S. Bajwa, A. E. Jacobson, K. C. Rice, R. A. Streaty and W. A. Klee, "Probes for Narcotic Receptor Mediated Phenomena. 7. Synthesis and Pharmacological Properties of Irreversible Ligands Specific for .Mu. or .Delta. Opiate Receptors,” Journal of Medicinal Chemistry, Vol. 27, No. 12, 1984, pp. 1570-1574. doi:10.1021/jm00378a008

[25] W. Walter and K.-D. Bode, "Syntheses of Thiocarbamates," Angewandte Chemie International Edition in English, Vol. 6, No. 4, 1967, pp. 281-293.

[26] E. Lieber and R. O. Orlowski, "Hydrazinolysis of 1-(Alkyldithioate)-Piperidine,” The Journal of Organic Chemistry, Vol. 22, No. 1, 1957, pp. 88-92.

[27] A. W. M. Lee, W. H. Chan, H. C. Wong and M. S. Wong, "One Pot Phase Transfer Synthesis of O-Alkyl, S-Methyl Dithiocarbonates (Xanthates)," Synthetic Communications, Vol. 19, No. 3-4, 1989, pp. 547-552.

[28] R. N. Salvatore, S. Sahab and K. W. Jung, "Mild and Efficient Synthesis of Thiocarbonates and Thiocarbamates via a Three-Component Coupling Utilizing $\mathrm{Cs}_{2} \mathrm{CO}_{3}$ and TBAI," Tetrahedron Letters, Vol. 42, No. 11, 2001, pp. 2055-2058.

[29] N. Azizi, F. Aryanasab and M. R. Saidi, "Straightforward and Highly Efficient Catalyst-Free One-Pot Synthesis of Dithiocarbamates under Solvent-Free Conditions," Organic Letters, Vol. 8, No. 23, 2006, pp. 5275-5277. doi:10.1021/ol0620141

[30] J. Tan, F. S. Liang, Y. M. Wang, X. Chang, Q. Liu and H. J. Yuan, "Carbon Tetrabromide-Mediated Carbon-Sulfur Bond Formation via a Sulfenyl Bromide Intermediate," Organic Letters, Vol. 10, No. 12, 2008, pp. 2485-2488. doi:10.1021/ol800765s

[31] S. Xia, X. Wang, Z.-M. Ge, T.-M. Cheng and R. T. Li, "An Efficient Synthesis of Aryldithiocarbamic Acid Esters from Michael Addition of Electron-Deficient Alkenes with Arylamines and $\mathrm{CS}_{2}$ in Solid Media Alkaline $\mathrm{Al}_{2} \mathrm{O}_{3}$," Tetrahedron, Vol. 65, No. 5, 2009, pp. 10051009. doi:10.1016/j.tet.2008.11.084

[32] N. Azizi, F. Aryanasab, L. Torkiyan, A. Ziyaei and M. R. Saidi, "One-Pot Synthesis of Dithiocarbamates Accelerated in Water," The Journal of Organic Chemistry, Vol. 71, No. 9, 2006, pp. 3634-3635. doi:10.1021/jo060048g

[33] D. Chaturvedi and S. Ray, “An Efficient, One-Pot, Synthesis of Dithiocarbamates from the Corresponding Alcohols using Mitsunobu's Reagent,” Tetrahedron Letters, Vol. 47, No. 20, 2006, pp. 1307-1309.

doi:10.1016/j.tetlet.2005.12.079

[34] T. Chung, H. Ishihara and S. A. Tejima, “A Facile Synthetic Approach for Alkyl $\alpha$-Glycosides of Reducing Disaccharides," Chemical \& Pharmaceutical Bulletin, Vol. 26, No. 5, 1978, pp. 1570-1575.

[35] S. Tsuboi, S. Takeda, Y. Yamasaki, T. Sakai, M. Utaka, S. Ishida, F. Yamada and J. Hirano, "A Convenient Synthesis of Platelet-Activating Factors and Their Analogs from Chiral Epichlor-ohydrine," Chemistry Letters, Vol. 21, No. 8, 1992, pp. 1417-1420. doi:10.1246/cl.1992.1417

[36] H. Natsugari, Y. Matsushita, N. Tamura, K. Yoshioko and M. Ochiai, "Synthesis of 5,6- cis-Carbapenems Related to C-19393 $\mathrm{H}_{2}$," Journal of the Chemical Society, Perkin Transactions 1, 1983, pp. 403-411. doi:10.1039/p19830000403

[37] I.-C. Chiu, US Patent No. 5560853, 1996 (CAN 125: 333865).

[38] L. Farng and A. G. Horodysky, US Patent No. 5019284, 
1991 (CAN 115: 236138).

[39] E. Kato, JP Patent No. 06019219, 1994 (CAN 121: 311855).

[40] E. Kato, JP Patent No. 04313763, 1992 (CAN 119: 213949).

[41] J.-L. Cui, Z.-M. Ge, T.-M. Cheng and R. T. Li, “An Efficient One-Pot Synthesis of 2-Hydroxyalkyl Dithiocarbamates," Synthetic Communications, Vol. 33, No. 12, 2003, pp. 1969-1976.

[42] N. Azizi, B. Pourhasan, F. Aryanasab and M. R. Saidi, “A Simple and Novel Eco-Friendly Process for the One-Pot Synthesis of Dithiocarbamates from Amines, Carbon Disulfide, and Epoxides," Synlett, No. 8, 2007, pp. 12391242.

[43] P. Werle, M. Trageser and S. Weiss, EP Patent No. 386508, 1990 (CAN 114: 184824).

[44] K. Itoh and K. Okonogi, EP Patent No. 446877, 1991 (CAN 115: 280032).

[45] R. A. Sheldon, "Green Solvents for Sustainable Organic Synthesis: State of the Art," Green Chemistry, Vol. 7, No. 5, 2005, pp. 267-278. doi:10.1039/b418069k.

[46] B. Movassagh and M. Soleiman-Beigi, "Stero- and Regioselective Thiolysis of 1,2-Epoxides in Water," Synthetic Communications, Vol. 37, No. 18, 2007, pp. 32393244. doi:10.1080/00397910701548100

[47] B. Movassagh and A. Mossadegh, "Reductive Cleavage of S-S Bond by $\mathrm{Zn} / \mathrm{AlCl}_{3}$ System: A Novel Method for the Synthesis of Sulfides from Alkyl Tosylates and Disulfides," Synthetic Communications, Vol. 34, No. 9, 2004, pp. 1685-1690.

[48] B. Movassagh and M. Shamsipoor, "Zinc-Mediated Cleavage of Diselenides: A Novel Synthesis of Unsymmetrical Diorganyl Selenides in Aqueous Media,” Synlett, No. 1, 2005, pp. 121-122.

[49] B. Movassagh and Y. Zakinezhad, "A New One-Pot Synthesis of Thiocarbamates from Isocyanates and Disulfides in the Presence of $\mathrm{Zn} / \mathrm{AlCl}_{3}$ System," Chemistry Letters, Vol. 34, No. 10, 2005, pp. 1330-1331. doi:10.1246/cl.2005.1330

[50] B. Movassagh and Y. Zakinezhad, "Formation of Zinc
Thiolates by Reductive Cleavage of Disulfides with the $\mathrm{Zn} / \mathrm{AlCl}_{3}$ System in Aqueous Media, and Their Use for Michael Addition," Zeitschrift für Naturforschung. B, A journal of chemical sciences, Vol. 61, No. 1, 2006, pp. 47-49.

[51] B. Movassagh and M. Navidi, "One-Pot Synthesis of Beta-Hydroxysulfides from Styrenes and Disulfides Using the $\mathrm{Zn} / \mathrm{AlCl}_{3}$ System," Tetrahedron Letters. Vol. 49, No. 17, 2008, pp. 6712-6714.

doi:10.1016/j.tetlet.2008.09.071

[52] S. Balalaie, M. Bararjanian, A. M. Amani and B. Movassagh, " $(S)$-Proline as a Neutral and Efficient Catalyst for the One-Pot Synthesis of Tetrahydrobenzo[b]pyran Derivatives in Aqueous Media," Synlett, No. 2, 2006, pp. 263-266. doi:10.1055/s-2006-926227

[53] B. Movassagh and A. Tatar, " $\mathrm{Zn} / \mathrm{RuCl}_{3}$-Promoted Cleavage of Diselenides: An Efficient Michael Addition of Zinc Selenolates to Conjugated Alkenes in Aqueous Media,” Synlett, Vol. 2007, No. 12, 2007, pp. 1954-1956. doi:10.1055/s-2007-984495

[54] B. Movassagh and A. Fazeli, "Zinc-Mediated Cleavage of Diselenides: A Novel Synthesis of Selenoformates in Aqueous Media,” Monatshefte für Chemie/Chemical Monthly, Vol. 138, No. 9, 2007, pp. 863-865. doi:10.1007/s00706-007-0642-1

[55] B. Movassagh and M. Navidi, "Water Promoted Catalyst-Free Anti-Markovnikov Addition of Thiols to Styrenes," Arkivok, 2008, pp. 47-53.

[56] B. Movassagh and P. Shaygan, "Michael Addition of Thiols to $\alpha, \beta$-Unsaturated Carbonyl Compounds Under Solvent-Free Conditions,” Arkivok, 2006, pp. 130-137.

[57] B. Movassagh and M. Soleiman-Beigi, "TriethylamineCatalyzed One-Pot Synthesis of Trithiocarbonates from Carbon Disulfide, Thiols, and Alkyl Halides in Water," Monatshefte für Chemie/Chemical Monthly, Vol. 139, No. 8, 2008, pp. 927-930. doi:10.1007/s00706-008-0864-x

[58] B. Movassagh and M. Soleiman-Beigi, "Synthesis of Sulfides under Solvent- and Catalyst-Free Conditions," Monatshefte für Chemie/Chemical Monthly, Vol. 140, No. 4, 2009, pp. 409-411. doi:10.1007/s00706-008-0043-0 